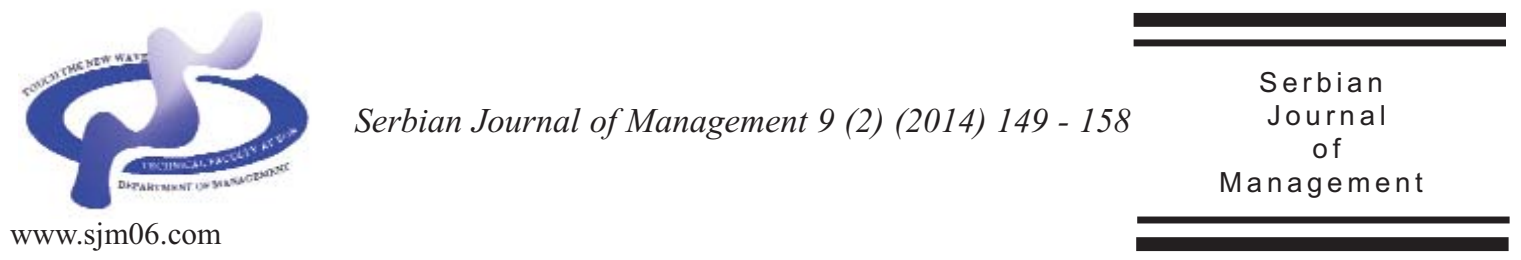

\title{
ENTREPRENEURS OF THE FUTURE
}

\author{
Kornélia Lazányi* \\ Óbuda University, Keleti Faculty of Business and Management \\ H-1034, Budapest, Becsi st 96/b, Hungary
}

(Received 23 May 2014; accepted 01 July 2014)

\begin{abstract}
Entrepreneurs are the gale of creative destruction. They are the engines of the local economy and contribute to a country's wealth to a great extent. Accordingly it is of utmost importance, to create educate and motivate - young adults to become entrepreneurs and start their own enterprises. The article summarises the basic facts about the Hungarian entrepreneurs' and small and medium sized companies' significance, and introduces a research on personal entrepreneurial competencies. The aim of the research is to explore the entrepreneurial potential of students in tertiary education, since they are the entrepreneurs of the future. In the research 470 young adults' (students of tertiary education) responses are compared with those of successful entrepreneurs. According to the results successful Hungarian entrepreneurs produced better results on the personal entrepreneurial competencies test, scoring in most cases higher than the members of the student sample. In addition to this, patterns based on age, gender and work experience could be identified.
\end{abstract}

Keywords: entrepreneurship, competencies, SME, Hungary

\section{INTRODUCTION}

According to Schumpeter (1934) entrepreneurship is the process by which the economy as a whole goes forward. Entrepreneurs and SMEs contribute to the economic growth to an enormous extent
(Szekeres, 2010; Francsovics \& Kadocsa, 2012). Small and medium-sized enterprises play a key role in the European economy (Borbás \& Kadocsa, 2010). More than 20 million SMEs employ about 87 million people (two thirds of the private sector employees). The value generated by the

\footnotetext{
* Corresponding author: lazanyi.kornelia@kgk.uni-obuda.hu
}

DOI:10.5937/sjm9-6257 
SMEs in the European Union is about 58\% of the total value added (European Commission, 2012).

However, due to the economic crisis, the income generation of and the employment within the sector fell in the past years (Csiszárik-Kocsir \& Medve, 2012). The corporate performance of the companies drastically decreased till 2010 (Deloitte, 2012) and the average firm size in the EU has been decreasing since 2005. It has dropped from 4.34, to 4.22 employees in average by 2012. Nevertheless, this seemingly small alteration - due to the large number of SMEs - is a significant change in economic measures.

In Hungary, the proportion of SMEs within the economy is even higher than that of the EU. Nevertheless, the real significant difference lies in the ratio of micro, small and medium-sized companies.

As it is displayed in Table 1, more than one third of the Hungarian active population is employed in micro sized companies, mostly family business. Accordingly it is of utmost importance, to create - educate and motivate - young adults to become entrepreneurs and start their own enterprises. Nevertheless, not anyone can become a successful entrepreneur. In line with the data presented in Table 1, although in average 7\% more are employed in micro sized companies in Hungary, the total value added by the sector is less than the EU average, and in proportion the difference is more than $20 \%$.

According to SBA data (SBA, 2012) Hungarian enterprises are lacking in all dimensions of effective performance excluding the responsive administration. There are even two SBA areas - "think small first" and "state aid on public procurement", - where the collective growth indicators for 2007-2012 were negative. What is more, according to the Global Entrepreneurship Monitor (2012) compared to other European businesses Hungarian enterprises are lacking in almost any aspects of entrepreneurship; among otherscompetencies and innovation, the core personal characteristics.

Since it is not in numbers but due to qualitative features the Hungarian SMEs are below the EU average in effectiveness, present paper endeavours to explore the features associated with entrepreneurship in international literature and investigate the competencies of the potential future Hungarian entrepreneurs compared to those currently running successful micro or smallsized ventures.

\section{E N T R E P R E N E U R I A L COMPETENCIES}

The necessary features, skillset and competencies of entrepreneurs have changed severely throughout the ages. According to Richard Cantillon (des Bruslons, 1723) - the

Table 1. SMEs in the European Union and in Hungary

\begin{tabular}{lcccccc}
\hline & \multicolumn{2}{c}{$\begin{array}{c}\text { Number } \\
(\%)\end{array}$} & \multicolumn{2}{c}{$\begin{array}{c}\text { People employed } \\
(\%)\end{array}$} & \multicolumn{2}{c}{$\begin{array}{c}\text { Value added } \\
(\%)\end{array}$} \\
\cline { 2 - 7 } & EU & Hungary & EU & Hungary & EU & Hungary \\
\hline Micro (0-9 employees) & 92.2 & 94.8 & 29.6 & $\mathbf{3 6 . 5}$ & 21.2 & 18.2 \\
Small (10-49 employees) & 6.5 & 4.4 & 20.6 & 19.3 & 18.5 & 15.9 \\
Medium (50-249 employees) & 1.1 & 0.7 & 17.2 & 16.9 & 18.4 & 19.5 \\
Big (in average 250 employees) & 0.2 & 0.1 & 32.6 & 27.1 & 41.9 & 46.2 \\
\hline
\end{tabular}

Source: KSH, 2013 
first person to define the notion of entrepreneurship - entrepreneurs are people who pay a certain price for a product to resell it at an uncertain price, making decisions about obtaining and using resources while consequently admitting the risk of enterprise. Hence, the centre of the very first definition of entrepreneurship was uncertainty tolerance and risk-taking. The focus remained unchanged for about two hundred years, until Schumpeter (1934) announced that risk taking is not a sufficient quality of entrepreneurs. According to his ideology, entrepreneurs are "wild spirits" whosignificantly differ from the rest of the population since they are highly creative and willing, what is more able to shatter the already existing processes and convert a new idea or invention into a successful innovation. By doing so entrepreneurs are the catalysts for economic change, the gales of creative destruction.

Schumpeter (1934), by introducing the heroic aspect of entrepreneurship started a quest for the answer to the question what characterises a successful entrepreneur. McClelland (1961) stated that only individuals with a high need for achievement can become entrepreneurs. Collins and Moore (1964) on the other hand declared the desire for independence to be the core of entrepreneurship. Shapero (1975), when addressing the same notion speaks about internal locus of control, the importance of the ability to neglect others' opinion. Equally, entrepreneurs cannot be hold back by others, who due to sheer risk-avoidance try to preserve the status quo. Wilken (1979) also emphasised, that the creative, innovative ideas that define an entrepreneur cannot be implemented, when concentrating on the opinion of the others, or on the restrictive nature of the current circumstances. For that reason, besides creativity, daring and aggressiveness are inevitable for long term success. In line with this Stevenson and Gumpert (1985) defined entrepreneurship as a mind-set, where - during the pursuit for opportunities - resources currently controlled are disregarded, creativity is not restricted by rationality, but fostered by the complete disregard of the previous, of the "objective" reality of the common crowd.

For a long time the career decision of being an entrepreneur was equal to that of being a self-made man, and the emphasis has been on self. Although it has been clear for long that entrepreneurs use and utilise various resources during their process of setting and managing a venture (TóthBordásnéMarosi, 2014), interpersonal relations and communication skills have only been added to the necessary prerequisites' list in the past 30 years.

Starr and MacMillan (1990) - on the basis of their researches - provedthat every business decision of entrepreneurs is socially embedded. Decisions are influenced by the social surrounding of the entrepreneur and the decisions influence these people in return. Hoang and Antoncic (2003) also state that entrepreneurs, as the companies they establish, are strongly connected to various other actors within their environment throughout their everyday operation. What is more, their social embeddedness influences the process of starting and operating their business venture as well (Singh, 2000; Ripolles \& Blesa, 2005; Anderson et al., 2005; De Clercq \& Arenius, 2006). Successful entrepreneurs build and utilise connections in order to gain human, financial and social support and other valuable resources, such as advice, information, funding, boost of credibility/reputation, social legitimacy, access to knowledge and 
skills and social support (Hansen, 2001; Klyver \& Hindle, 2007). Accordingly, networking skills, such as communication and negotiation skills, emotional intelligence, and competencies connected to power positions, such as leadership and delegation are also indispensable.

In line with this, when researching the entrepreneurial competencies, we have taken the broadest definition into consideration, concentrating not only on risk taking, but skills and competencies as well.

\section{RESEARCH QUESTION, METHOD AND PARTICIPANTS}

The aim of present study was to determine, whether students of tertiary education have the necessary skills and competencies to start successful businesses, whether they are lacking or over-performing the entrepreneurs in the sample. Accordingly two basic research questions have been investigated:

1. Do entrepreneurs perform better, than students; and if yes, in which personal entrepreneurial competencies?

2. Does the gender, age or the work experience significantly influence the levels of distinct competencies?

In order to measure the skills and competencies of successful entrepreneurs and 'entrepreneur-to-be's the PEC test (Personal Entrepreneurial Competencies) of McClelland (1987) have been translated and adapted to Hungarian. The test investigates 13 factors connected to the notion of entrepreneurship with the help of 70 statements that should be rated on a five point Likert scale. The factors measured are the following:
1. Taking initiative: taking actions that go beyond the job requirements and are not dictated by other people, along with acting ahead of others, hence defining and leading a successful venture.

2. See and act on opportunities: recognising and seizing opportunities.

3. Persistence: the mentality according to which obstacles are there to overcome them, even if repeated actions and additional effort is required.

4. Information Seeking: searching data and information pre and proactively to help achieve business objectives or clarify business problems.

5. Concern for High Quality of Work: meeting a self-defined standard of excellence gives entrepreneurs greater satisfaction.

6. Commitment to Work Contract: putting emphasis on getting a job completed.

7. Efficiency Orientation: striving to do things faster, with fewer resources, or at a lower cost.

8. Systematic Planning: developing and using logical, step-by-step plans to reach goals.

9. Problem Solving: identifying new and potentially unique ideas to achieve business goals.

10. Self-Confidence: a strong belief in self and own abilities.

11. Assertiveness: confronting problems and issues with others directly.

12. Persuasion: persuading or influencing others to mobilise resources, obtain inputs, organise production and sell products.

13. Use of Influence Strategies: making use of influential people to reach business goals.

Besides these 70 questions, basic data on the age, gender and working experience of the research participants have been gathered. 
The research has been made in the first quartile of 2014 on two separate samples. On the one hand, students from tertiary education, namely Óbuda University, Széchényi István University and Szent István University have filled out this questionnaire as a compulsory activity within various classes connected to entrepreneurship (such as Family Businesses, Entrepreneurship Development, Establishing of a Business Venture, ...). On the other hand, with the help of the students of the previously defined sample, "successful" Hungarian micro and small enterprises have been contacted, where success has been defined with a simple indicator - positive net income in the year 2013. The basic criterion of selection has been that the research participants had to be the establishers of their own venture, and had to set up their own company within the past two years. This latter criterion was important, since the aim of the research has been to determine, whether the entrepreneurs possess a better entrepreneurial skillset than the students in tertiary education.

The research has been made in the first quartile of 2014 on two separate samples. On the one hand, students from tertiary education, namely Óbuda University, Széchényi István University and Szent István University have filled out this questionnaire as a compulsory activity within various classes connected to entrepreneurship (such as Family Businesses, Entrepreneurship Development, Establishing of a Business Venture, ...). On the other hand, with the help of the students of the previously defined sample, "successful" Hungarian micro and small enterprises have been contacted, where success has been defined with a simple indicator - positive net income in the year 2013. The basic criterion of selection has been that the research participants had to be the establishers of their own venture, and had to set up their own company within the past two years. This latter criterion was important, since the aim of the research has been to determine, whether the entrepreneurs possess a better entrepreneurial skillset than the students in tertiary education.

\section{RESULTS AND DISCUSSION}

In order to answer the first question, namely whether and in what factors are the competencies of successful entrepreneurs better, than that of students, the 13 personal entrepreneurial competence factors have been generated - each of them as a sum of 5 relevant questions. Since each statement could be rated on a 5 points Likert scale, the values of the factors could range from 5 to 25. The average scores of the two samples are displayed on Figure 1.

As it can be seen on Figure 1, the students' average scores were lower than those of the entrepreneurs in case of 7 personal competencies. The greatest difference (2.05 points) occurred with the feature 'Taking initiative'. Accordingly, students of tertiary education are different from successful entrepreneurs in not taking the initiative, not acting ahead of others in seizing opportunities consciously. Surprisingly, there were factors, where students were the ones to over-perform entrepreneurs. The greatest discrepancy was in the feature of 'Self-confidence'. The possible explanation behind these results may lie in the fact that students barely have work experience, and barely had the opportunity to face the hardships of the working life and experience negative impulses, which could affect their selfesteem negatively (This hypothesis is tested 


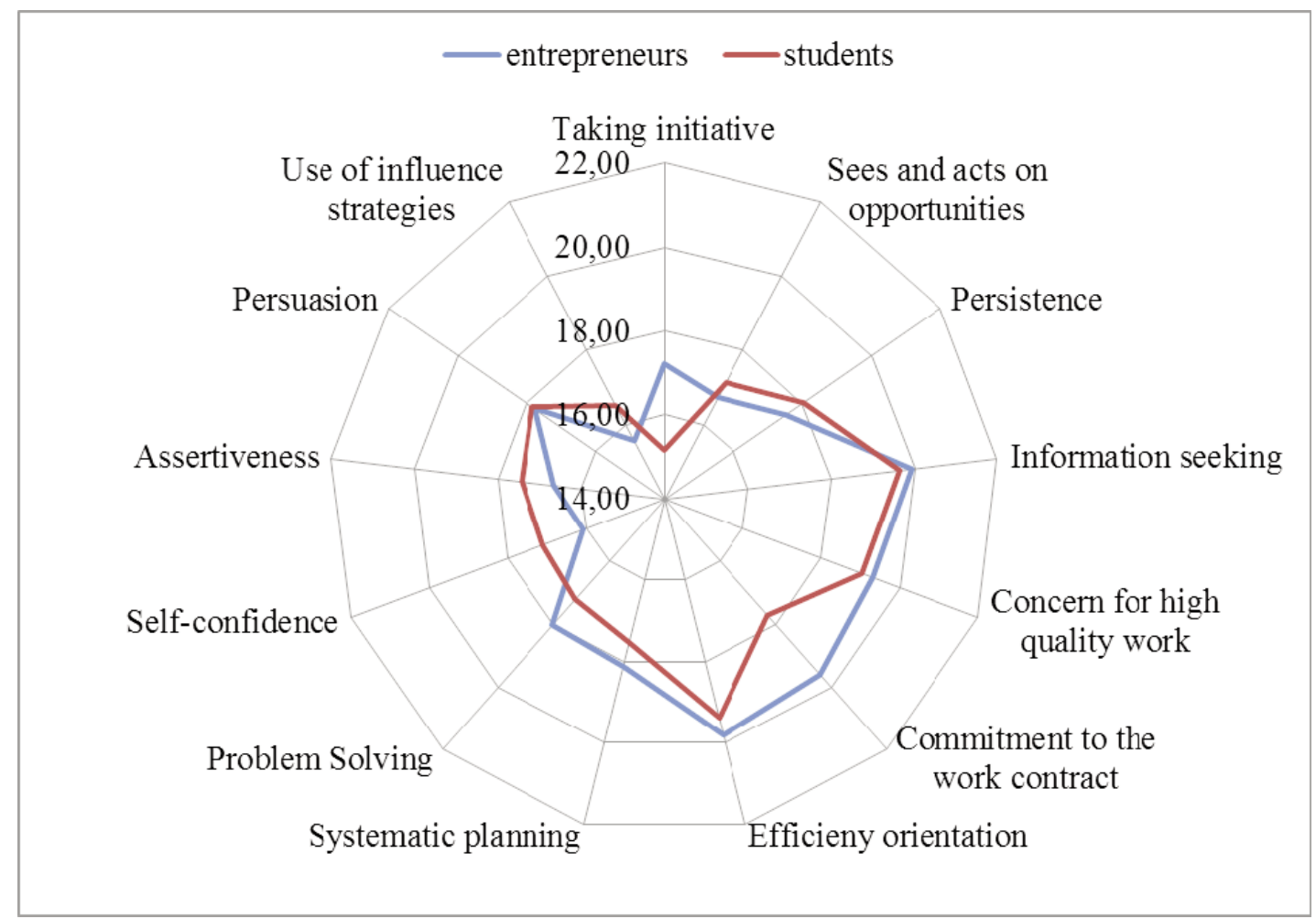

Figure 1. Average scores of the two samples

with the help of the second research question).

In order to see, whether the differences displayed on Figure 1 are significant, an independent samples t-test has been performed with the help of an SPSS 20 program. The significant results of the calculation are displayed in Table 2 .

As a result, besides the already mentioned two features, an additional quality 'Commitment to the work contract' has been identified, where the means of the two samples has significantly been different. Consequently, we can state, that the entrepreneurs researched were far more committed to fulfilling their work contract, than the students participating in the research. With this feature as well, the hypothesised source of the difference lies in the (lack of) work experience.

In order to answer the second question, the bivariate correlation of the demographic variables and the personal entrepreneurial competence factors has been generated in

\section{Table 2. T-test for Equality of Means}

\begin{tabular}{|c|c|c|c|c|c|c|c|}
\hline & \multirow[b]{2}{*}{$\mathrm{t}$} & \multirow[b]{2}{*}{ df } & \multirow{2}{*}{$\begin{array}{c}\text { Sig. } \\
\text { (2-tailed) }\end{array}$} & \multirow{2}{*}{$\begin{array}{l}\text { Diff. of } \\
\text { Means }\end{array}$} & \multirow{2}{*}{$\begin{array}{l}\text { Std. Error } \\
\text { of Diff. }\end{array}$} & \multicolumn{2}{|c|}{$\begin{array}{l}95 \% \text { Confidence Interval } \\
\text { of the Difference }\end{array}$} \\
\hline & & & & & & Lower & Upper \\
\hline Taking initiative & 4.086 & 39.157 & .000 & 2.054 & .503 & 1.037 & 3.071 \\
\hline Self-confidence & -2.793 & 48.190 & .007 & -1.019 & .365 & -1.752 & -.285 \\
\hline $\begin{array}{l}\text { Commitment to the } \\
\text { work contract }\end{array}$ & 3.649 & 37.972 & .001 & 1.872 & .513 & .834 & 2.911 \\
\hline
\end{tabular}


each sample separately. Personal demographic variables, such as age, gender, highest level of education, along with two features connected to work (total work experience in months, longest duration of working for the same company) have been investigated. Interestingly the correlations within the two samples were different. The significant correlations of the entrepreneurs are displayed in Table 3, and those of the students are presented in Table 4.

In line with Table 3, out of the 13 factors of personal entrepreneurial competencies only 5 had significant correlations with demographic variables, however, the correlation in most of the cases was only significant at the 0.05 level (signalled with *). The only strong correlation however has been significant at the 0.01 level (signalled with $* *)$.

Since the age of respondents within the first sample was ranging from 24 to 56 years within the sample two significant, although not really strong correlations could be detected, stating that the respondents' concern for high quality work and their persistence increases with age. Interestingly, female respondents performed better than males in the information seeking factor, meaning that searching data and information pre and proactively to help achieve business objectives or clarify business problems is an easier task for them.

According to data presented in Table 3, the higher educational level the respondents had, the more concern they had for the quality of their work. It is also visible that the level of education had a positive connection with the respondents' conscious information seeking attitude.

Astonishingly, the length of work experience did not show significant correlation with any of the personal entrepreneurial competencies; however, the duration of the longest work experience produced some significant results. Surprising as it may be, the longer the respondents worked for the same company, the more selfconfident, and assertive they were. The possible reason for this connection is, that those, who are more self-conscious, and are able to communicate assertively could spend more time in the same position in the pat, than those, who did not possess these traits.

Compared to the sample of entrepreneurs, that of the students did not display any strong correlations. What is more, every significant correlation was very weak (under 0.12), which, taking the big size of the sample into consideration, is close to non-existent.

Table 3. Correlation of the demographic variables and the personal entrepreneurial competence factors on the sample of entrepreneurs

\begin{tabular}{|c|c|c|c|c|}
\hline & Age & Gender & $\begin{array}{l}\text { Level of } \\
\text { education }\end{array}$ & $\begin{array}{l}\text { Duration of } \\
\text { longest job }\end{array}$ \\
\hline Persistence & $\begin{array}{c}0.355^{*} \\
(0.037)\end{array}$ & & & \\
\hline Information seeking & & $\begin{array}{c}0.352^{*} \\
(0.038)\end{array}$ & $\begin{array}{c}0.337^{*} \\
(0.048)\end{array}$ & \\
\hline Concern for high quality work & $\begin{array}{c}0.362^{*} \\
(0.032)\end{array}$ & & $\begin{array}{l}0.574^{* *} \\
(0.000)\end{array}$ & \\
\hline Self-confidence & & & & $\begin{array}{c}0.378^{*} \\
(0.025)\end{array}$ \\
\hline Assertiveness & & & & $\begin{array}{c}0.394^{*} \\
(0.019)\end{array}$ \\
\hline
\end{tabular}


Table 4. Correlation of the demographic variables and the personal entrepreneurial competence factors on the sample of students

\begin{tabular}{|c|c|c|c|}
\hline & Age & Gender & Work experiene \\
\hline Taking initiative & $\begin{array}{l}0.097^{*} \\
(0.036)\end{array}$ & & $\begin{array}{l}0.119^{* *} \\
(0.010)\end{array}$ \\
\hline Sees and acts on opportunities & & & $\begin{array}{l}0.124^{* *} \\
(0.007)\end{array}$ \\
\hline Information seeking & & $\begin{array}{l}0.103^{*} \\
(0.026)\end{array}$ & \\
\hline Concern for high quality work & & $\begin{array}{l}0.098^{*} \\
(0.034)\end{array}$ & $\begin{array}{l}0.103^{*} \\
(0.026)\end{array}$ \\
\hline Commitment to the work contract & & $\begin{array}{l}0.146^{* *} \\
(0.002)\end{array}$ & \\
\hline Systematic planning & & & $\begin{array}{l}0.117^{*} \\
(0.011)\end{array}$ \\
\hline Problem Solving & & & $\begin{array}{l}0.114^{*} \\
(0.013)\end{array}$ \\
\hline Self-confidence & & & $\begin{array}{l}0.106^{*} \\
(0.021)\end{array}$ \\
\hline Persuasion & & & $\begin{array}{c}0.111^{*} \\
(0.016)\end{array}$ \\
\hline Use of influence strategies & & & $\begin{array}{l}0.105^{*} \\
(0.023)\end{array}$ \\
\hline
\end{tabular}

However, as a general tendency it can be deduced, that female respondents performed better than male students, and the length of the students' work-experience also had positive correlation with the level of their personal entrepreneurial competencies.

\section{CONCLUSION}

As a general rule, the successful Hungarian entrepreneurs, who have participated in the research, produced better results on the questionnaire, scoring in most cases higher than the members of the student sample. Additionally - in line with the statistics previously introduced entrepreneurs researched were far more committed to fulfilling their work contract, and taking initiative, than the students participating in the survey. Perversely, students had significantly more selfconfidence, than successful entrepreneurs.
The age, gender and work experience of the respondents did have significant correlations (though in many cases only weak) with personal entrepreneurial competencies. However, the connections were different in the two sample and hence do not provide a solid ground for general laws on the relation examined.

The competencies within the entrepreneurs' sample were of higher level for those older, or with higher level of education, or longer period of working at the same company. Additionally, the respondents' answers also differed by age suggesting that aging is maturing and increases the level of entrepreneurial competencies - and by gender in favour of the female respondents.

The entrepreneurial competencies of the students had positive, but very week connections with the age and work experience of the respondents, supporting the maturing "hypothesis", and females in 
this sample as well scored significantly higher on some personal entrepreneurial competencies than male respondents.

All in all, young adults - students in tertiary education - still have a room for improvement concerning their personal entrepreneurial competencies.

\section{ПРЕДУЗЕТНИЦИ БУДУЋНОСТИ}

\section{Kornélia Lazányi}

\section{Извод}

Предузетници су прави представници тзв. “креативне деструкције”. Они представљају мотор локалне привреде и значајно доприносе добробити државе. Самим тиме, најважније је да се створе - едукују и мотивишу - млади како би постали предузетници и покренули сопствени посао. Овај рад сумира основне чињенице о предузетницима у Мађарској, као и о значају малих и средњих предузећа и уводи истраживање о личним компетенцијама предузетника. Циљ истраживања је проучити предузетнички потенцијал студената на нивоу високог образовања, јер су они потенцијални предузетници будућности. У току истраживања добијено је 470 одговора на упитнике, од стране студената, и упоређено са одговорима успешних предузетника. На основу резултата, може се рећи да су успешни предузетници остварили боље резултате на тесту личних предузетничких компетенција, у односу на студенте. Такође, проучаван је утицај година, пола и радног искуства на добијене одговоре.

Кључне речи: предузетништво, компетенције, МСП, Мађарска

\section{References}

Anderson, A.R., Jack, S.L., \& Dodd, S.D. (2005). The role of family members in entrepreneurial networks: Beyond the boundaries of the family firm. Family Business Review, 18 (2), 135- 154.

Borbás, L., \& Kadocsa, Gy. (2010). Possible ways for improving the competitiveness of SMEs: A CentralEuropean approach, MEB 2010: 8. Budapest: Óbuda University, 103-123.

Collins, O., \& Moore, D. (1964). Enterprising man, Bureau of Business and Economic Research, Graduate School of Business Administration, Michigan State University. East Lansing: Michigan State University.
Csiszárik-Kocsir, A., \& Medve, A. (2012). The perception of the recession due to the effects of the economic crisis in view of the questionnaire-based research results. MEB 2012: 10. Budapest: Óbuda University, 263-272.

De Clercq, D., \& Arenius, P. (2006). The role of knowledge in business start-up activity. International Small Business Journal, 24, 339-358.

Deloitte. (2012). The national SMEs' access to financial resources and the assessment of deficiencies and weaknesses of the markets (in Hungarian). Budapest. Deloitte Hungary.

Des Bruslons, S. (1723). Universal Dictionary of Trade (in French), Paris: Chez al Veuve Estienne. 
European Comission, Directorate- Comission.

General Enterprise and Industry. (2012). Flash Eurobarometer 354. Enterpreneurship in the EU. European Comission.

Francsovics, A., \& Kadocsa, Gy. (2012). The Comparative analysis of the competitiveness of SMEs in Hungary (in German). MEB 2012: 10. Budapest: Óbuda University, 115-131.

GEM (2012). The Global Entrepreneurship Monitor [online] Available at: $<$ http://www.gemconsortium.org $>$, [Accessed 07 February 2014].

Hansen, E.L. (2001). Resource acquisition as a startup process: Initial stocks of social capital and organizational foundings. [online] Available at: $<$ http://www.babson.edu/entrep/fer/IV/IVB/ html/Iv-B.html $>$, [Accessed 07 December 2013].

Hoang, H., \& Antoncic, B. (2003). Network-based research in entrepreneurship - A critical review. Journal of Business Venturing, 18, 165-187.

Klyver, K., \& Hindle, K. (2007). The role of social networks at different stages of business formation. Small Business Research, 15 (1), 22-37.

KSH (2013).The situation of SMEs in Hungary (in Hungarian). Statisztikaitükör, 7 (108).

McClelland, D. (1961). The Achieving Society. Princeton: D Van Nostrand.

McClelland, D.C. (1987). Characteristics of Successful Entrepreneurs. Journal of Creative Behavior, 21 (3), 219-233.

Ripolles, M., \& Blesa, A. (2005). Personal networks as fosterers of entrepreneurial orientation in newventures. International Journal of Entrepreneurship and Innovation, 6, 239-248.

SBA (2012). Enterprise and Industry: SBA Fact Sheet 2012 - Hungary. European
Schumpeter, J. (1934). Theory of Economic Development (in German), Berlin: Duncker Humbolt.

Shapero, A. (1975). The Displaced, Uncomfortable Entrepreneur, Psychology Today, 9 (6), 83-88.

Singh, R.P. (2000). Entrepreneurial opportunity recognition through social networks, London: Garland Publiching Inc.

Starr, J.A., \& MacMillan, I.C. (1990). Resource Cooptation Via Social Contracting: Resource Acquisition Strategies for New Ventures. Strategic Management Journal, 11, 79-92.

Stevenson, H.H., \& Gumpert, D.E. (1985). The heart of entrepreneurship. Harvard Business Review, 85 (2), 85-94.

Szekeres, V. (2010). Gender and its relevance to economic performance, MEB 2010: 8. Budapest: Óbuda University, 217224.

Tóth-BordásnéMarosi， I. (2014): The Value-Creating Role of Family Socialization in Operating Family Businesses. 11th Annual International Conference on Economics and Business Challenges in the Carpathian Basin: Global challenges, local answers. Csíkszereda - Seklerburg - Miercurea Ciuc, S.C. Roprint S.R.L, 488-502.

Wilken, Ph.H. (1979). A comparative and historical study. Norwood: Ablex Publishing Corporation. 